\title{
ポリ塩化ビニル延伸フィルムの分子配向と機械的性質*
}

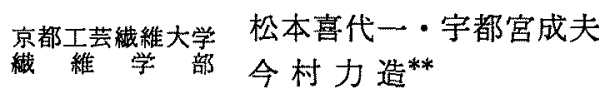

\section{RELATION BETWEEN MOLECULAR ORIENTATION AND MECHANICAL PROPERTIES OF STRETCHED POLYVINYLCHLORIDE FILMS*} \\ By Kiyoichi Matsumoto, Shigeo Utsunomiya and Rikizo Imamura** \\ (Faculty of Textile Science, Kyoto University of Industrial Arts \\ and Textile Fibers, Sakyo-ku, Kyoto, Japan)
}

\begin{abstract}
The report deals with the relationship between the changing molecular orientation and some mechanical properties of polyvinylchloride films prepared by the different types of stretching. For the estimation of the orientation the birefringences were measured by using a tilting technique and mechanical properties are discussed by stress-strain curves.
\end{abstract}

The following results were obtained :

(1) The molecular orientation of uniaxially stretched films under free width, is radial symmetry around the drawing direction. For the uniaxially stretched films with constant width, however, the orientation is more or less biaxial. The difference of mechanical properties can be related to the difference of orientation.

(2) In the two-way successively biaxially stretched films, the "balance point of orientation" were the degrees of chain orientation are equal in the directions of the first and second stretching agrees with the "balance point of mechanical properties".

(3) In the simultaneously biaxially stretching, the balanced films whose mechanical properties are isotropic in the film plane are obtained independently of the stretch ratio.

Thus, the simultaneously biaxial stretching is more excellent and useful for the stretching of non crystalline polymer films such as polyvinylchloride as well as for crystalline polymer films.

Presented partly before the 21st Annual Meeting of the Chemical Society, Japan, Kansai University, Osaka, March, 1968.

(Received September 16, 1969)

\section{1. 緒言}

本研究は，非晶性のポリ塩化ビニルフィルムの延伸に 伴う分子配向の変化と，延伸に伴うフィルムの機械的性 質の変化を﨎応させて検討することを目的として行なっ た。ただし延伸方式として，自由輻一軸，一定幅一軸， 逐次二軸，同時二軸を比較したが，このよらに延伸方式

*この報文を「フィルムの二軸趠伸们関する研究（第 3 報)」「Studies on the biaxially stretching of films (Part 3)」とする。

** 現在の所征; 京都大学農学部 (京都市左京区) Present adress ; Faculty of Agriculture, Kyoto University, Sakyo-ku, Kyoto, Japan)
が多彼に亘り，かつ複雑になると，分子鎖の配向を示す のに，従来の方法は不十分であるといわねばならな iso

本研究では分子鎖の配向の測定に際し，Stein ${ }^{1)}$ によ って創始され，河合ら によょって補足された試料㑯斜法 による複屈折測定を行なった。この方法による測定結果 はこれを3角座標として表示できるが，このことは延伸 による分子配向の経過を適確に示し得る点で極めて有用 である。

な叔筆者らは先に，ポソプロピレンフィルムの延伸に 伴う分子配向をX線的方法で解析し，かつその結果をつ ィルムの機㑘的性質の变化と関連させて考察したが本研 
究の検討に際し、この既往の研究結果との対比にる注意 を払っだ。

\section{2. 实 験 法}

\section{$2 \cdot 1$ 試料および延伸法}

前報4) と同一の試料を使用し，また延伸装置，延伸法 などす前報と同㥞である。

\section{$2 \cdot 2$ 傾斜法による椱届折の測定}

(1) 装 置

河合らの方法に準じて，通常の複屈折测定装埴に取り つけたニニパーサルステージに，試料を装着する。光源 には白色光を用い, コンペンセータとしてはペレック型 を使用した。そのケ方向と試料のMD方向とを直交させ MD 万向を回転軸として, 試料を等間隔に $0 \sim 45$ 度㖽斜 させて溳定した。

（2）延伸倍率およびフィルムの擪さの湘定

第 1 報3)のと就り。

(3) 複屆折の算出

上記のように白帒光を光源とし， ニンペンセータの回 転角を変えて，0次の干渉縞が現われた時のレターデー ション $\Gamma_{c}$ を睄定する。複屈折 $(\Delta n)$ はこの上5にし て測定したコンペンセータの $\Gamma_{c}[\mathrm{~m} \mu]$ を次式に入れて 算出した。

$$
\begin{aligned}
& \Delta n=1 / d \cdot\left\{(n+1) \lambda-\Gamma_{c}\right\} \\
& \Delta n=1 / d \cdot\left\{n \lambda+\Gamma_{c}\right\}
\end{aligned}
$$

ここで， $\lambda$ は光源の波長， $d$ は試料中の光路長である。

（4）試料を傾斜させた場合の試料の厚さの計算

通常の光学系において厚さ $d_{0}$ のフィルム面に光が入 射した時の笪屈折度は $\Delta n=\Gamma / d_{0}$ であるが，图 1 のよ

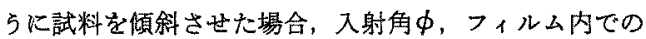
屈折角 $r$ の時の光路長，すなわち，傾斜時の補正厚さ $d(\equiv \overline{P Q})$ は，河合らにより次式のよ5に算出されている が，本研究でもこの式を用いて算出した。

$$
d=\frac{d_{0}}{\sqrt{1-\frac{\sin ^{2} \phi}{\bar{n}^{2}}}}
$$

(5) 三主㾉折率 $(\alpha, \beta, \gamma)$ の計算

Stein の報告》に準じて，次のように計算した。すな わち、フィルム面に光を西值に入射させた場合の複屈 折 $(\gamma-\beta)$ と中だけ傾斜させた試料を測定した複屈折 $(\gamma-\delta)$ とから, $(\alpha-\beta)$ の算出は次式による。

$$
(\alpha-\beta)=[(\gamma-\beta)-(\gamma-\delta)] / \sin ^{2} \gamma
$$

たたし，棈円面 $\left(x^{2} / a^{2}+y^{2} / b^{2}+z^{2} / c^{2}=1\right)$ を $x y$ 面で切 つた場合を考え，図１亿おいて紙面に垂直な軸を回転軸 として試料を傾斜させると，観測される複屈折は（ $\alpha$ -

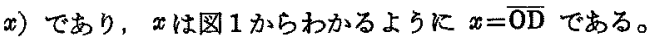

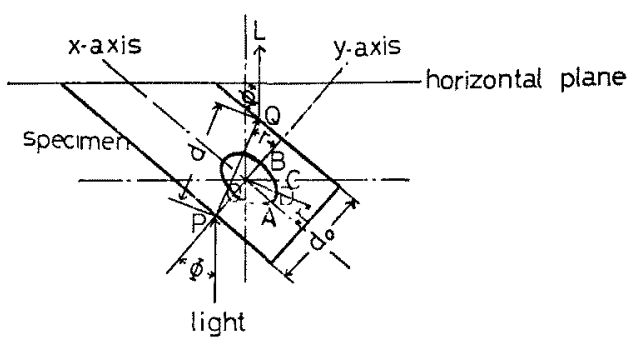

Fig. 1. Light path in tilting specimen. Light path $P, Q \& L ; d_{0}$, film thickness.

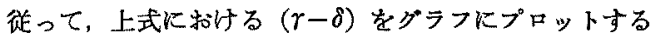
に際しては $(\gamma-\delta)$ 対 $\phi$ ではなく， $(\gamma-\delta)$ 对 $r$ を用 弓。申と $\gamma$ の関係は屈折の法則からわかるように, 各試 料特有の閶係をむつ。また述のことは， $\alpha, \beta, \gamma か ゙ わ$ かると任意の角 $r$ での就屈折が数学的に計算可能でるる ことを意味し，2軸性の棈円体の場合での回転軸が MD またはTD方向のいずれか一方のデータから他方のデー タをチェックするのに役立つ。

(6) 3 軸の配向係数の計算

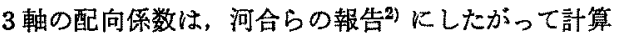
した。すなわち，コンペンセータが試料のMD方向に垂 直で，回転軸が試料の $\mathrm{MD}$ 方向と平行である場合には， $x, y, z \quad 3$ 軸の複屈折は, それそれ $\Delta x=\gamma-\beta, \Delta y=\gamma$ $-\alpha, \Delta z=\alpha-\beta$ として表わされる。

次に屈折率回転棈円体を考党, 分子鎖セグメントが ON 方向を中心方向として分布しているとし， ON が $x, y, z の 3$ 軸となす角をとれぞれ $\phi_{x}, \phi_{y}, \phi_{z}$ とすると， 河合らによ礼ば次式が成立する。

$$
\begin{aligned}
& \left\{\begin{array}{l}
\alpha=\left(n_{\|}-n_{\perp}\right) \overline{\cos ^{2}} \phi_{x}+n_{\perp} \\
\beta=\left(n_{\|}-n_{\perp}\right) \overline{\cos }^{2} \phi_{y}+n_{\perp} \\
\gamma=\left(n_{\|}-n_{\perp}\right) \overline{\cos }^{2} \phi_{z}+n_{\perp}
\end{array}\right. \\
& \overline{\cos ^{2}} \phi_{x}+\overline{\cos ^{2}} \phi_{y}+\overline{\cos ^{2}} \phi_{z}=1
\end{aligned}
$$

先の測定值 $\alpha, \beta, \gamma$ を上式に代入して連立方程式を解 いて 3 方向の配向係数 $\overline{\cos ^{2}} \phi_{x}, \overline{\cos ^{2}} \phi_{y}, \overline{\cos ^{2}} \phi_{z}$ を求め る。これら 3 方向の配向係数を図3〜5のよらにDesper によって提案された正 3 解图に準じてブロットすれ ば，分子鎖セグメントの各軸となす平均角度を適切に表 現し得る。なお，分子配向分布はそれぞれの頂点に近い ほど，分子鎖セグメントがその軸に平行に配向している ことを示し，それと逆の方向に扣いては，その軸と垂直 沉配向していることを付言しておく。

本報告において， PVCフィルムの固有複屈折度 $\left(n_{\|}\right.$ $\left.-n_{\perp}\right)$ は 0.0102 を用い, 平均屈折率 $\bar{n}=(\alpha+\beta+\gamma) /$ 3 は 1.544 を用いだ? 
Table 1. Birefringence and orientation coefficients of stretched PVC films.

\begin{tabular}{|c|c|c|c|c|c|c|c|c|c|}
\hline \multirow{2}{*}{ No. } & \multicolumn{2}{|c|}{ stretch } & \multirow{2}{*}{$\begin{array}{c}\text { thickness } \\
{[\mu]}\end{array}$} & \multicolumn{3}{|c|}{ birefringence, $\times 10^{9}$} & \multicolumn{3}{|c|}{ orientation coefficient } \\
\hline & method & $\begin{array}{c}\text { str. ratio } \\
(\mathrm{MD} \times \mathrm{TD})\end{array}$ & & $\Delta x$ & $\Delta y$ & $\Delta z$ & $\overline{\cos ^{2}} \phi_{x}$ & $\overline{\cos ^{2}} \phi_{y}$ & $\overline{\cos ^{2}} \phi_{z}$ \\
\hline 1 & non & $1.0 \times 1.0$ & 240 & 0.0000 & 0.0012 & -0.0012 & 0.3333 & 0.3334 & 0.3334 \\
\hline 2 & \multirow{8}{*}{ 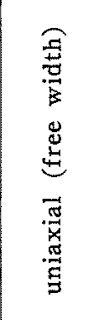 } & $1.5 \times 1^{\prime}$ & 172 & 1.209 & 1.212 & -0.0028 & 0.2903 & 0.2906 & 0.4091 \\
\hline 3 & & $2.0 \times 1^{\prime}$ & 151 & 2.431 & 2.440 & +0.210 & 0.2676 & 0.2470 & 0.4853 \\
\hline 4 & & $2.5 \times 1^{\prime}$ & 128 & 3.554 & 3.793 & -0.239 & 0.2221 & 0.2198 & 0.5682 \\
\hline 5 & & $3.0 \times 1^{\prime}$ & 125 & 4.443 & 4.483 & -0.040 & 0.1855 & 0.1894 & 0.6250 \\
\hline 6 & & $3.5 \times 1^{\prime}$ & 121 & 4.740 & 4.792 & -0.052 & 0.1750 & 0.1801 & 0.6448 \\
\hline 7 & & $4.0 \times 1^{\prime}$ & 115 & 5.330 & 5.706 & -0.376 & 0.1346 & 0.1715 & 0.6940 \\
\hline 8 & & $4.5 \times 1^{\prime}$ & 155 & 5.909 & 6.154 & -0.245 & 0.1242 & 0.1482 & 0.7275 \\
\hline 9 & & $5.0 \times 1^{\prime}$ & 95 & 6.453 & 6.532 & -0.079 & 0.1173 & 0.1250 & 0.7576 \\
\hline 10 & \multirow{6}{*}{ 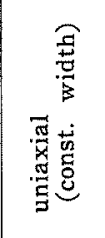 } & $1.5 \times 1.0$ & 150 & 1. 100 & 1.880 & -0.780 & 0.2464 & 0.3229 & 0.4307 \\
\hline 11 & & $2.0 \times 1.0$ & 120 & 2.300 & 3.012 & -0.712 & 0.2116 & 0.2814 & 0.5069 \\
\hline 12 & & $2.5 \times 1.0$ & 100 & 2.990 & 3.866 & -0.876 & 0.1784 & 0.2643 & 0.5574 \\
\hline 13 & & $3.0 \times 1.0$ & 80 & 3.510 & 4.570 & -1.060 & 0.1494 & 0.2533 & 0.5974 \\
\hline 14 & & $3.5 \times 1.0$ & 60 & 3.694 & 4.942 & -1.248 & 0.1310 & 0.2534 & 0.6156 \\
\hline 15 & & $4.0 \times 1.0$ & 55 & 4.836 & 5.797 & -0.961 & 0.1145 & 0.2087 & 0.6828 \\
\hline 16 & \multirow{8}{*}{ 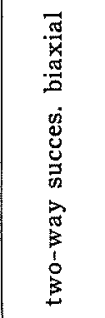 } & $2.0 \times 1.5$ & 75 & 1. 155 & 2.695 & -1.540 & 0.1949 & 0.3459 & 0.4592 \\
\hline 17 & & $2.0 \times 2.0$ & 67 & 0.420 & 2.220 & -1.800 & 0.2019 & 0.3784 & 0.4196 \\
\hline 18 & & $2.0 \times 2.5$ & 54 & 1.423 & 3. 343 & -1.920 & 0.1612 & 0.4892 & 0.3497 \\
\hline 19 & & $2.0 \times 3.0$ & 39 & 1.865 & 4.585 & -1.720 & 0.1600 & 0.5114 & 0.3286 \\
\hline 20 & & $3.0 \times 1.5$ & 52 & 2.218 & 3.380 & -1.170 & 0.1844 & 0.2991 & 0.5166 \\
\hline 21 & & $3.0 \times 2.0$ & 32 & 1.894 & 3.284 & -1.390 & 0.1806 & 0.3169 & 0.5026 \\
\hline 22 & & $3.0 \times 2.5$ & 29 & 0.430 & 2.680 & -2.250 & 0.1722 & 0.3928 & 0.4350 \\
\hline 23 & & $3.0 \times 3.0$ & 28 & 0.161 & 2.819 & -2.658 & 0.1543 & 0.4149 & 0.4307 \\
\hline 24 & \multirow{4}{*}{ 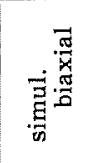 } & $1.5 \times 1.5$ & 102 & 0.0782 & 1. 208 & -1.130 & 0.2568 & 0.3677 & 0.3754 \\
\hline 25 & & $2.0 \times 2.0$ & 52 & 0.2230 & 2.273 & -2.050 & 0.1920 & 0.3930 & 0.4149 \\
\hline 26 & & $2.5 \times 2.5$ & 32 & 0.0588 & 2.459 & -2.404 & 0.1762 & 0.4119 & 0.4177 \\
\hline 27 & & $3.0 \times 3.0$ & 20 & 0.1391 & 2.322 & -2.191 & 0.1856 & 0.4004 & 0.4140 \\
\hline
\end{tabular}

島津オートグラフ IM 100 型を使用し，試料寸法は夕 ンザク型 $5 \mathrm{~mm} \times 50 \mathrm{~mm}$ ，条件は温湿度 $20^{\circ} \mathrm{C}, 65 \% \mathrm{R}$. H., 湘定長 $20 \mathrm{~mm}$, 引張速度 $50 \% / \mathrm{min}$ である。湘定 項目は引張強さ，破堎伸び，ヤング率就よび分子鎖の tautness を表わす $F_{5}$ (值名をを測定した。

\section{3. 実験結果之考察}

表 1〜2 には，供試フィルムを各種延伸方式每化所定 倍率延伸し, 得られるフィルムの分子配向度拉上び機械 的性質の測定結果を一括して示した。ここにみられるよ 5に，延伸フィルムは各延伸方式每にそれそれ特徵のあ る性質をもたらし，またそれそれ分子配向の效果を如実 に反映している。以下これらの延伸機構と機械的性質と を関連させながら考察する。

\section{$3 \cdot 1$ 未延伸フィルム}

この場合の $\mathrm{MD}, \mathrm{TD}, \mathrm{ThD} 3$ 方向の複屈折 $\Delta z, \Delta y$ 怙よび $\Delta x$ はいずれる0で为って無配向を示す。従って 配向係数は $\overline{\cos ^{2}} \phi_{x}=\overline{\cos ^{2}} \phi_{y}=\overline{\cos ^{2}} \phi_{z}$ であり, $\overline{\cos ^{2} \phi_{x}+}$ $\overline{\cos }^{2} \phi_{y}+\overline{\cos }^{2} \phi_{z}=1$ の関係からいずれも0.333 となる。 因 3〜5 に打当点(A)はこの位置を示す。

ただし，Tダイ成膜したフィルムは，一般にMD方向 に多少とも配向する傾向をもつが，本研究のフィルム は，成膜に際してのドラフト率が極度に小さく，このた め汪とんど無配向なことは上述にみら机るとおりであ る。なお，このフィルムは MD，TD 拉よびその中間の 方向でいずれの機械的性質も等しい。

\section{2 自由幅一軸延伸フィルム}

この場合（ここでは MD方向の延伸に限る）の複屈折 
Table 2. Mechanical properties of stretched polyvinylchloride films. Material; polyvinylchloride film prepared by T-die process. Medium of stretching; hot dry-air.

\begin{tabular}{|c|c|c|c|c|c|c|c|c|c|}
\hline \multirow{2}{*}{$\begin{array}{l}\text { Methods of } \\
\text { stretching. }\end{array}$} & \multirow{2}{*}{$\begin{array}{l}\text { Ratio of } \\
\text { stretching. } \\
(M D \times T D)\end{array}$} & \multicolumn{2}{|c|}{$\begin{array}{c}\text { Tensile strength, } \\
\mathrm{kg} / \mathrm{mm}^{2}\end{array}$} & \multicolumn{2}{|c|}{$\begin{array}{c}\text { Elongation at } \\
\text { break, } \%\end{array}$} & \multicolumn{2}{|c|}{$\begin{array}{l}\text { Young's modu- } \\
\text { lus, } \mathrm{kg} / \mathrm{mm}^{2}\end{array}$} & \multicolumn{2}{|c|}{$\begin{array}{r}\mathrm{F}_{5} \text {-value, } \\
\mathrm{kg} / \mathrm{mm}^{2}\end{array}$} \\
\hline & & $\mathrm{MD}$ & $\mathrm{TD}$ & $M D$ & $T D$ & $\mathrm{MD}$ & $\mathrm{TD}$ & $\mathrm{MD}$ & $\mathrm{TD}$ \\
\hline unstretched. & $\begin{array}{c}\text { no heat-set } \\
1.0 \times 1.0\end{array}$ & 3.6 & 3. 5 & 190 & 190 & 134 & 134 & 4.9 & 4.8 \\
\hline \multirow{6}{*}{$\begin{array}{l}\text { Uniaxially } \\
\text { stretched under } \\
\text { the conditions of } \\
\text { free width. }\end{array}$} & $1.5 \times 1^{\prime}$ & 5.2 & 2.8 & 250 & 110 & 80 & 60 & 3.4 & 2.8 \\
\hline & $2.0 \times 1^{\prime}$ & 6.5 & 3.0 & 180 & 6 & 97 & 58 & 4.2 & 2.6 \\
\hline & $2.5 \times 1^{\prime}$ & 11.1 & 3.1 & 110 & 6 & 108 & 62 & 4.9 & 2.7 \\
\hline & $3.0 \times 1^{\prime}$ & 13.0 & 2.1 & 43 & 2 & 247 & 122 & 7.9 & - \\
\hline & $4.0 \times 1^{\prime}$ & 16.3 & 1.5 & 25 & 1 & 275 & 115 & 8.9 & - \\
\hline & $5.0 \times 1^{\prime}$ & 20.9 & - & 24 & - & 328 & - & 11.6 & - \\
\hline \multirow{5}{*}{$\begin{array}{l}\text { Uniaxially stret- } \\
\text { ched under the } \\
\text { conditions of con- } \\
\text { stant width. }\end{array}$} & $1.5 \times 1.0$ & 5.5 & 3.2 & 140 & 210 & 152 & 130 & 5.1 & 3.5 \\
\hline & $2.0 \times 1.0$ & 8.5 & 3.2 & 120 & 240 & 117 & 73 & 5.4 & 3.2 \\
\hline & $2.5 \times 1.0$ & 11.9 & 3.3 & 44 & 192 & 125 & 59 & 5.1 & 2.7 \\
\hline & $3.0 \times 1.0$ & 13.9 & 3.4 & 28 & 135 & 148 & 76 & 7.0 & 3.4 \\
\hline & $4.0 \times 1.0$ & 14.8 & 3.7 & 17 & 56 & 280 & 165 & 10.8 & $?$ \\
\hline \multirow{8}{*}{$\begin{array}{l}\text { Two-way succe- } \\
\text { ssively biaxially } \\
\text { stretched. }\end{array}$} & $2.0 \times 1.5$ & 7.3 & 4.8 & 140 & 230 & 99 & 91 & 4.6 & 4.0 \\
\hline & $2.0 \times 2.0$ & 6.5 & 6.4 & 170 & 210 & 89 & 89 & 4.0 & 4.1 \\
\hline & $2.0 \times 2.5$ & 7.7 & 9.1 & 95 & 36 & 224 & 264 & 6.2 & 7.4 \\
\hline & $2.0 \times 3.0$ & 6.9 & 9.9 & 98 & 30 & 236 & 288 & 5.2 & 8.1 \\
\hline & $3.0 \times 1.5$ & 12.0 & 5.8 & 36 & 140 & 334 & 185 & 8.9 & 5.6 \\
\hline & $3.0 \times 2.0$ & 11.5 & 6.8 & 32 & 89 & 306 & 220 & 8.3 & 6.2 \\
\hline & $3.0 \times 2.5$ & 10.4 & 6.9 & 38 & 40 & 286 & 245 & 7.4 & 5.8 \\
\hline & $3.0 \times 3.0$ & 7.2 & 7.5 & 33 & 3 & 261 & 249 & 6.0 & 6.0 \\
\hline \multirow{4}{*}{$\begin{array}{l}\text { Simultaneously } \\
\text { biaxially } \\
\text { stretched. }\end{array}$} & $1.5 \times 1.5$ & 5.9 & 5.8 & 160 & 140 & $\mathfrak{I} 77$ & 176 & 4.8 & 5.9 \\
\hline & $2.0 \times 2.0$ & 7.0 & 6.5 & 50 & 50 & 234 & 240 & 6.2 & 5.6 \\
\hline & $2.5 \times 2.5$ & 9.3 & 9.2 & 28 & 29 & 266 & 264 & 7.0 & 7.0 \\
\hline & $3.0 \times 3.0$ & 9.4 & 9.4 & 28 & 24 & 302 & 282 & 8.0 & 7.8 \\
\hline
\end{tabular}

の変化を図 2 (a) K示す。この結果からかかるように， 延伸に伴いTD と $\mathrm{ThD}$ の両方向で, 複屈折性同等僧 大し，MD 方向では忹とんそ变化がない。これを分子配 淌俰数江換算して図示すると，図3の上5になる。この 結果は，分子鎖が延伸倍率の增加に伴い，幅と厚さ等 (い割合に減少し (前報) 図 3 参照)，一方，TD，ThD 両方向に対するバランスを保ちながら，(B)〜(I) 八と MD 方向に平行汇配向することを示す。換言すれ就，分 子鎖は延伸方向炕平行に，が円筒対称型分布をしなが ら一軸配向する。

この誉動は機械的性質によく反映している。すなわち 図 6〜9の各(a)にみられるように，MD一軸延伸に伴 って, 引張強さは MD 方向に增大し $\mathrm{TD}$ 方向では減少 終局的にはフィブリル化するといった一般的な傾向を示 す。また，ヤング率や $F_{5}$ 値についても，低延伸時の特 異見象是（配向の乱机基因すると考学的る）を含め
通常の結晶性高分子，たと齐ばポリプロピレンと類似の 傾向を示ず9。ここで最も特徽的な挙動は破壊伸びであ る。これ結晶性高分子の場合とは大いに翼なり，TD 方向の伸びの減少が著しい。このことはとりる直さず， 非晶鎖セグメントのみで構成されている PVC の場合, その自由幅一軸登伸フィルムの TD 方向の破壊仕事量 が，MD方向に比へ極端に小さいことを示唆し，一般的 な用途には不適当な性質をるたらしていると解喽され る。

\section{$3 \cdot 3$ 一定幅一軸延伸フィルム}

幅（TD 方向）を一定汇固定した一軸延伸フィルムの MD 方向の複屈折怯, 因 2 (b) に示すようK, 自由輻一 朝延伸のそ九と異なり，TD 万向に多少とも配向したよ らな二軸延伸的配向の挙勤を示す。また，延伸倍率が 1.5 倍㑢与る前飞, 延伸方向の複屈折がかなり大きく 隇少することは注意を要する。これを図4のように正三 

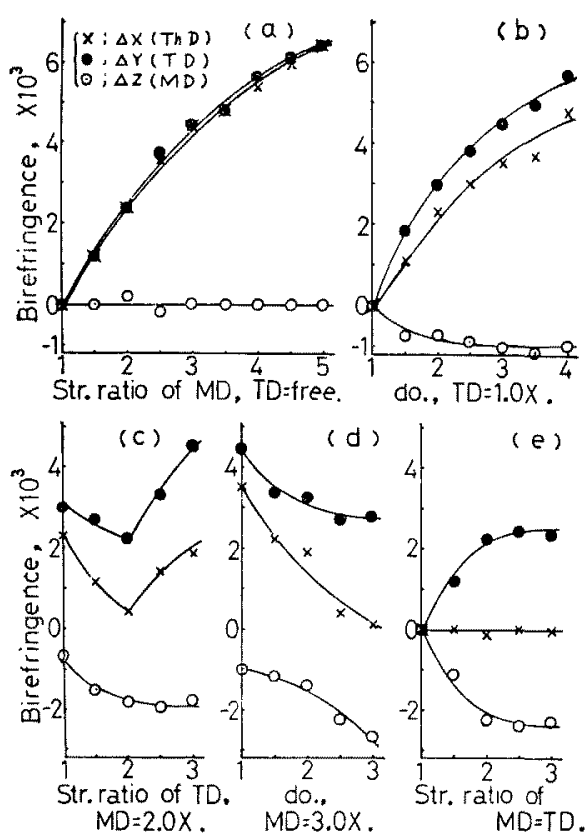

Fig. 2. Birefringence of stretched PVC films. (a); uniaxially stretched films (free-width), (b); uniaxially stretched films, (constant-width), (c) \& (d) ; two-way successively biaxially stretched films, first-way stretching by MD $=2 \mathrm{X}$ and $3 \mathrm{X}$, (e) ; simultaneously biaxially stretched films.

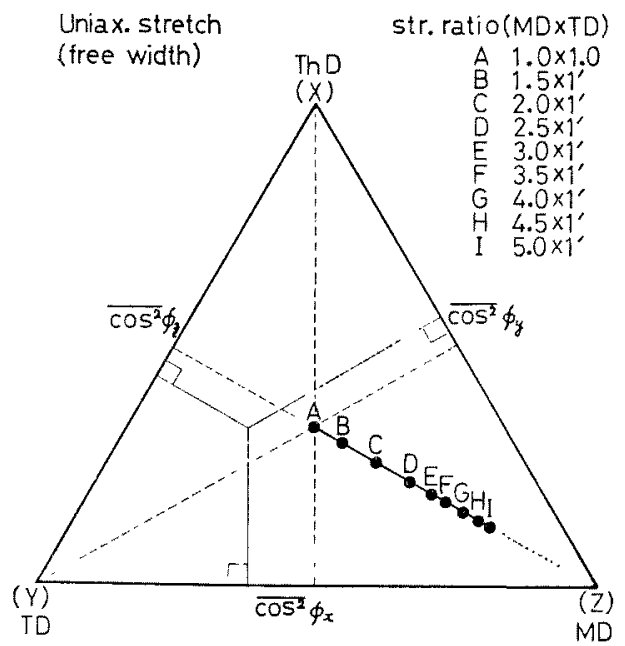

Fig. 3. Orientation coefficients of free-width uniaxially stretched PVC films. ThD, TD and MD; thickness, transverse and machine direction, $A \sim \mathrm{I}$; stretch ratio $\mathrm{MD} \times \mathrm{TD}=1.0 \times 1.0 \sim 5.0$ $\times 1^{\prime}$.
角図表に図示して考察すると，幅が固定されているね め，MD一軸延伸と同時にTD方向の収穛に抵抗する応 力が発生してその力向にる配向し，減少するのは厚さ方 向だけといらことになる。なお，1.5倍延伸までに((A) 〜 (B)）急激な配向をし，その後，分子鑽七グメントは $\mathrm{MD}$ 方向に平行に一軸配向する $((\mathrm{B}) \sim(\mathrm{G}))$ ことす気付 かれる。この点に関しては，第 1 報で，ポリプロピレン フィルムの結晶配向につき指摘したことと類似してい る。

この延伸方式によりもたらされる機柣的性質の変化を 図 6〜9 の各(b)に図示した。これからわかるように， いずれも自由幅一軸延伸の場合と異なる。引張強さの MD 万向の増大は前者程著しくはなく, 一方 TD方向の 減少はほとんよ゙双られない。次に破壊伸びについてで あるが，艺の低延伸領域で举動は通常の高分子の場合 と類似の傾向を示すが，高延伸になると、フィブリル化 現象が発現し，TD 万向の伸びならびに破壇仕事が激減 する。さらにヤング率についても，非晶性高分子特有と 考えられる低延伸倍率での配向の乱れないしは不完全さ の存在する領域に和ける低下を除くと，高分子フィルム の延伸の際にみられる一般的な傾向を示寸が，ヤング染 の低下か゚TD方向で特に著しいことも認められる。しか し，分子鎖の tautness 表わす $\mathrm{F}_{5}$ 值は， $\mathrm{MD}$ 方向で 低下することなく漸增するが，この現象は，この延伸方 式での分子鎖の配向挙動と考文合わ地て與味深い。

一方，一定幅 TD一軸延伸では，フィルムの分子配向

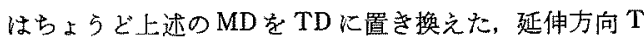
$\mathrm{D}$ K平行な一軸配向となる $\left((\mathrm{A}) \sim\left(\mathrm{G}^{\prime}\right)\right)$ 。このフィルム の機诚的性質も同様の分子配向を考学れば了解できる。

\subsection{2 段逐次二軸延伸フィルム}

第 1 段をMD方向に 2 倍あるいは 3 倍延伸して後、T D 方向に延伸した 2 段逐次二韩延伸フィルムの複屈折は 図2（c)挌よび(d)に示したよ5に，一軸延伸とは全く 変わった挙動を示す。特に，前段 2 倍延伸の場合には， 後段の延伸に伴って減少した複屈折が，徭段 2 倍延伸以 後で増加する傾向を示す。これは前段の延伸で一軸配向 した分子鎖セグメントが延伸倍率の等しい点で一度 MD， TD 両方向にパランスした配向状態をとり，をの後延伸 倍率の增加に伴って TD 一軸配向に似た配向に移り代わ ることに起因すると解してよく，このことは図 4 の正 3 角图表によって一層明確に理解できる。すなおちこの 場合の分子鎖セグメントは後段の延伸倍率の增加に伴 い, ((C)〜 $(\mathrm{H})) ，$ フィルム面にわずかではあるが倒れ てきて, $\mathrm{MD} \times \mathrm{TD}=2.0 \times 2.0$ の延伸倍率の点( I )で $\mathrm{M}$ D, TD 両方向への配向がくシランス寸る傾向が女る。さ らに延伸が進もとフィルム面に平行な配向を堌加しなが 


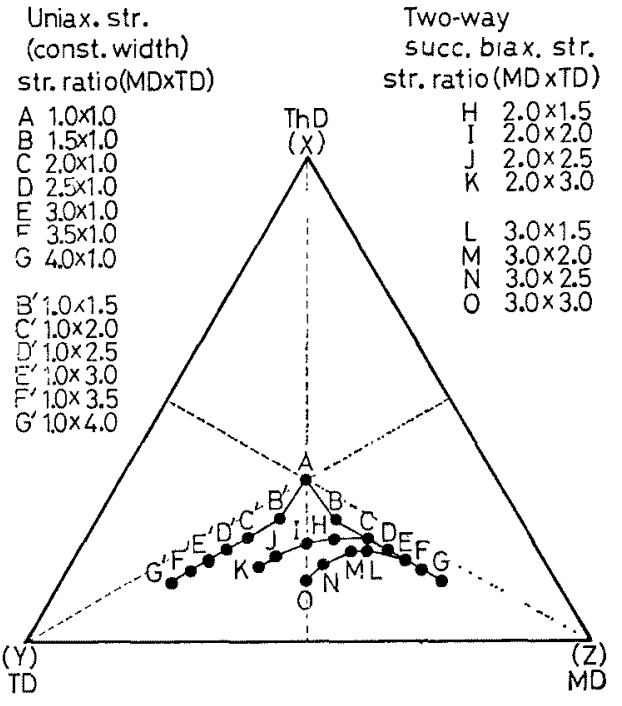

Fig.4. Orientation coefficients of constant-width uniaxially stretched PVC films and two-way successively biaxially stretched films. $A \sim G$; stretch ratio $\mathrm{MD} \times \mathrm{TD}=1.0 \times 1.0 \sim 4.0 \times 1.0$, $\mathrm{B}^{\prime} \sim \mathrm{G}^{\prime} ; 1.0 \times 1.5 \sim 1.0 \times 4.0, \quad \mathrm{H} \sim \mathrm{K} ; 2.0 \times 1.5$ $\sim 2.0 \times 3.0$, L $\sim 0 ; 3.0 \times 1.5 \sim 3.0 \times 3.0$

ら，TD 方向に優先的に配向する $((\mathrm{J}) \sim(\mathrm{K}))$ 。このよ ら汇両方向への延伸倍率が等しい時に，両方向への配向 もバランスすることは非晶性高分子フィルムにみられ る現象で, 結晶性高分子フィルムでは, 結晶化など複雑 な因子が加方って配向のバランス点は単に延伸倍率たけ で汢決定されないのは，前報タ)のと括りである。

一方, 前段 3 倍延伸の場合は, 後段の延伸に起因する 配向の乱れが前者の前段 2 倍延伸の場合よりも大きい。

すなわち，後段の低倍率延伸では，分子鎖セグメント

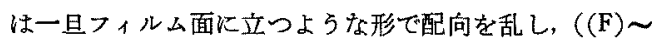
(N))，その後TD 方向へ配向しながら，フィルム面に倒 れてくる。やがて後段延伸 3 倍に至って, MD と TD両 方向への配向がパランス寸る。また， $2.0 \times 3.0(\mathrm{~K})$ と $3.0 \times 2.0(\mathrm{M})$ の上らな全延伸倍率が等しく, 前段の延 伸倍率の違う点を比べてみると，(M) 点上りも $(\mathrm{K})$ 点の ほらが分子鎖は上り一層フィルム面に平行に配向してい る。詳しくは後の研究で検討する。

以上の上らな分子配向挙動法, 逐次二軸延伸フィルム の機城的性筫に上く反映しているが，これ性図 6〜9の

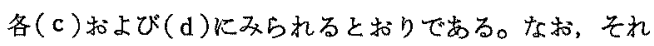
ぞれの配向のバランス点で，機械的性質むバランスして いることに注意されたい。この現象は，延伸フィルムの 性質が分子鎖セグメントの配向のみに依存寸る非晶性高
Simul. biax, str.

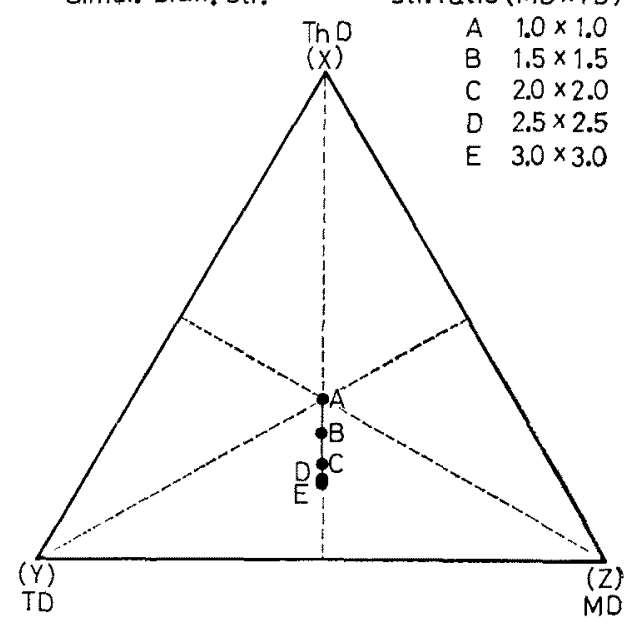

Fig. 5. Orientation coefficients of simultaneously biaxially stretched PVC films. A E ; stretch ratio $\mathrm{MD} \times \mathrm{TD}=1.0 \times 1 \cdot 0 \sim 3.0 \times 3.5$

分子フィルムに特有の現象であって，微結晶も関与する 結晶性高分子フィルムには見られない。また，延伸倍率 $\mathrm{MD} \times \mathrm{TD}$ が $2 \times 3$ と $3 \times 2$ とでは, 結局 MD と TD の值を入れ代えてみれ代同等となることも，上述と同様 の分子鎖の配向挙動によって説明される。さらに, バラ ンス点以降で MD, TD 共に引張強ざ, ヤング率および $\mathrm{F}_{\mathbf{5}}$ 値が增加し，伸びが減少することが認められるが， これも結晶性高分子フィルムの場合と異なった挙動であ る。主太，第 1 段の延伸倍率の大小によってヤング率と $\mathrm{F}_{5}$ 値がかなり変化することが知られるが，この現象る 第 1 段の延伸倍率の設定の重要さを示昗する。

3.5 同時二軸延伸フィルム

$\mathrm{MD}, \mathrm{TD}$ 両方向を同時に同倍率延伸した場合の複屈折 の挙動は、図2（e）にみられると拈りである。すなわち 延伸伴い $\mathrm{ThD}$ 方向の $\Delta x$ の変化は洼とんとなく。 $\mathrm{MD}, \mathrm{TD}$ 両方向の $\Delta z$ 之 $\Delta y$ の值が正負対称的倿化 する。

これを図 5 に示されているように，三角座標に直して 考察すると，延伸倍率の增加に伴い，分子鎖せグメント は面内の特定の方向炡配向することなく，終始 MD, TD 両方向にバランスを保らながら，すなわち面内ランダム のまま，ThD 方向に垂直に，換言するとフィルム面に 平行に配向するが $((\mathrm{B}) \sim(\mathrm{E}))$ ，このよらな挙動山第 1 報》に淤方結晶の配向挙動とよく類似している。

PVC の同時二軸延伸フィルムの機珹的性質は，上述 のよらな分子配向挙動から予想されるように，MD，TD およびその中間の総ての方向について差違がなく，ょく 


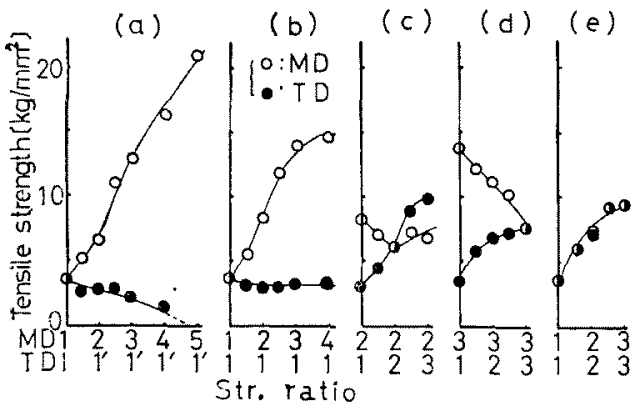

Fig.6. Tensile strength of variously stretched PVC films. Circles, MD ; points, TD. (a) ; uniaxially stretched films (free-width), (b) ; uniaxially stretched films (constant-width), (c) \& (d) ; two-way successively biaxially stretched films, first-way stretching by $M D=2 X$ and 3 $\mathrm{X}$, (e) ; simultaneously biaxially stretched films.

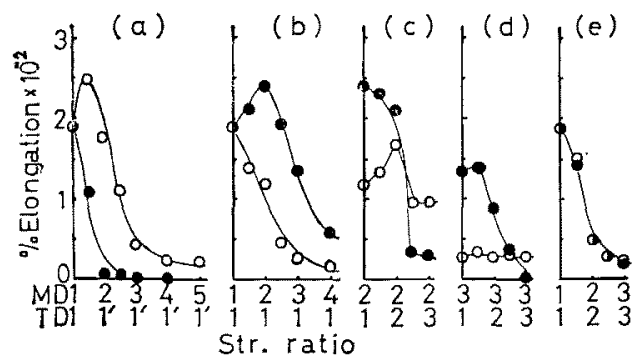

Fig. 7. \%-Elongation at break of variously stretched PVC films.

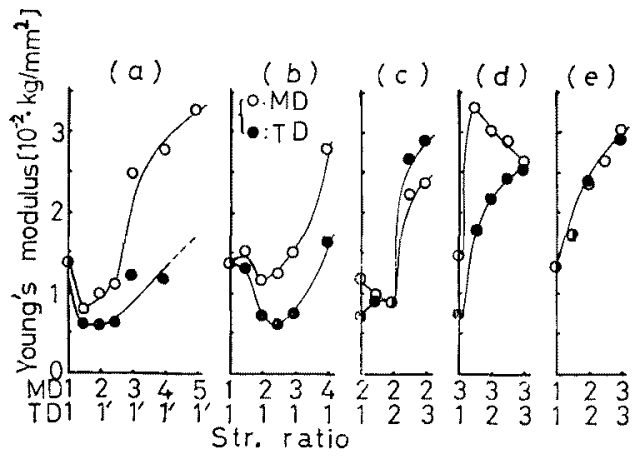

Fig. 8. Young's modulus of variously stretched PVC films.

ハランスした性質をるたらしている。これを図 6〜9の 各(e)に示ら。ここで、どらら分子鎖がかなりよく伸 張されているが，同時二軸延伸フィルムと配向挙動が上 述の上らに罢なる逐次二軸延伸フィルムとを同倍率，た

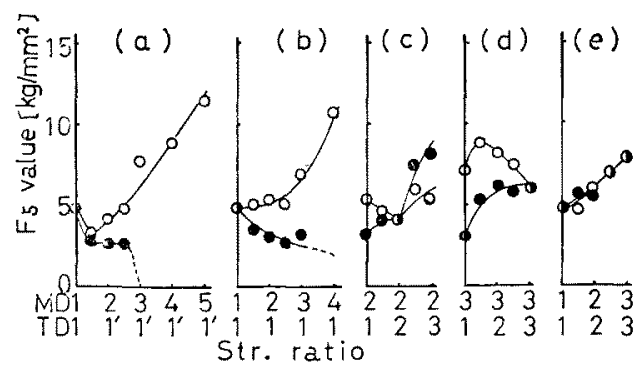

Fig. 9. $F_{5}$ value of variously stretched PVC films.

と壳ば $\mathrm{MD} \times \mathrm{TD}=3 \times 3$ について対比してみよう。この 場合，前者のほらが優れた機珹的性質をるつことは四か ら明らかである。また，配向挙動の相違以外に，それに 伴亏分子鎖の伸張程度に相違があると解される低毕伸倍 率，たと梳 $\mathrm{MD} \times \mathrm{TD}=2 \times 2$ の場合についてる，前者 の機珹的性質が後者のそれにまさり，ここでる同時二軸 延伸の有利さと，その方式で得られたフィルムの显秀性 加知和る。

\section{4. 結語}

以上を総括すると，PVC 非晶性高分子の各種延伸フ ィルムの分子配向挙動もまた，第 1 報引で図解して結論 ふけたポリプロピレン結晶性高分子フィルムの場合々同 様である。ただし本報では，その配向挙動をより一䚄定 量的に検討し得たわけであり，それたけに機械的性質之 の関連性む明確になった。

なかでも特記すべき事項は，次のよらである。

（1）自由幅一軸延伸フィルムと一定幅一軸延伸フィ ルムの分子鎖セグメントは，いずれも一洞様に延伸方 向に平行に一軸配向する。ただし，後者はTD方向の収 稉に抵抗する応力が影響して二軸的配向の傾向を示すが 前者にはその傾向は全くない。この相進が各機诚的性質 を特徽づけている。

（2）逐次二軸延伸フィルムの分子配向は, 前段の延 伸方向への一軸配向から後段の延伸に移った際に一旦配 向が乱れ，バランス点を経て，それ以降は後段の延伸方 向に再配向する。この場合，バランス点は 2 方向の延伸 倍率が等しい時に機械的性䓄筫も李しいといら非晶性 高分子フィルム特有の挙動を示す。の現象はこのよ うなフィルムの機栈的性質が分子鎖セグメントの配向の 欢依存していることを推定させる。

（3）逐次二軸延伸に标いては，第 1 段の延伸倍率の 設定が重要であるとともに，第 2 段のバランス点以降の 延伸によって付与される機械的性貿は, 他の結晶性高分 子フィルムの昜合とは翼なった効果なるたらす。 
（4）同時二軸延伸フィルムでは，分子鎖せグメント はフィルム面に平行に，面内でランダムに配向する。ま た，延伸倍率の如何を問わず，任意の方向にバランスの とれた榎れた機械的性質をもたらす。従って，非昆性亮 分子フィルムの延伸に就いて，同時二軸延伸法は最も優 れたまたバランスのとれた延伸フィルムを作製するの に最も有利な万法と考学てよからら。

[付 記]

本研究を行ならに当り，種々ご指導を頂いた京都大学 工学部河合弘廸教授, 高原弘和氏打よびご協力下さった 京都工芸繊維大学斌維学部清造岡助教授はじめ同研究室 の諸氏に感謝します。

な特，本研究の一部は昭和 42 年 4 月および昭和 43 年 3 月の日本化学会年会（第 20 年会和よび第 21 年会） において講演発表した。

\section{文献}

1) R.S.Stein ; J.Polymer Sci., 24, 383 (1957)
2) H. Kawai, H. Takahara et al, ; J. Polymer Sci., A-2, 6, 197 (1968)

3）今村力造，松本喜代一，貴村 且；䄉学誌，24, 277 (1968)

4）松本喜代一，板越利紀，今村力造；䋐学誌，25, 272 (1970)

5) C. R. Desper et al.; J. Appl. Phys., 37, 3990 (1966)

6）高分子実験学講座，4，108（1959），共立出版

7）プラスチックスの成形加工(高分子協会) 5(1964) など

8) C. J. Heffelfinger, P. G. Schmidt ; $J$. Appl. Polymer Sci., 9, 2661 (1965)

9）今村力造，松本玨代一ら；第 18 回高分子年次大 会讙演発表（昭 44.5）京都 松本喜代一, 石井浩一, 今村力造；絩学誌（投稿中 No. 2934)

10) R.D.Andrews, Y.Kazama ; J.Appl. Phys., 39, 4891 (1968) 